\title{
Civitas antigua y formación de las estructuras personales
}

\section{Ancient civitas and developing of personal structures}

\begin{abstract}
The concept of the city (civitas) does not necessarily have to mean an urban organization. It may mean a collection of localities, or a territory where some ethnic groups live (tribu). First of all, the development of personal structures happened initially in the families and was connected with a domestic cult. With time, several families used to make a separate group called fratria and a collection of them made up a tribu. This article shows how religion and a way of ruling affected the development of personal structures. Examples of this include are colonies and dioceses - personal structures of the Roman Empire.

The task which lies before this article is to enlighten the reader that many of the modern personal structures, especially those deep-rooted in canon law, have had a source in ancient civitas. Present structures of Catholic Church have their basis on that original classification: a family, fratria, tribu. Today there exist: a parish, a vicariate forane, a diocese, and a collection of dioceses called an ecclesiastical province.
\end{abstract}

\section{Keywords}

Civitas, Conception of the city, Personal structurs, tribu.

El concepto civitas no implica necesariamente el de una organización urbana. Puede designar también un complejo de pueblos o el territorio de una tribu. Cada ciudad poseía una extensa zona rural que formaba con ella una unidad política, social y económica. En la ciudad se concentraba la vida civilizada. 
Como una consecuencia de la entrada de Roma en oriente y de su interés por las ciudades, la sociedad urbana se hizo más compleja. Los grupos de forasteros se fueron formando durante un largo período en todas las ciudades: comerciantes y artesanos que seguían a los ejércitos o buscaban mejores mercados, personas caídas en esclavitud, exiliados políticos. Ahora bien, éstos residentes, no ciudadanos, conservaban a menudo cierto sentido de identidad étnico a la hora de establecer cultos locales de sus dioses nativos o de formar una asociación, que ofrecía, al menos, las apariencias de una religión. Los diferentes grupos de la ciudad y, dentro de cada grupo, personas de diferente status social se sentían afectados en mayor o menor grado por la hegemonía de Roma. La ciudad, pues, era el lugar donde se podía tomar contacto con la nueva civilización, donde se tropezaba con las novedades.

\section{La fratría y la tribu}

El culto doméstico se realizaba en el seno de la familia. La religión doméstica prohibía a dos familias mezclarse e identificarse. Pero había la posibilidad de que varias familias, sin sacrificar nada de su religión particular, pudieran unirse para celebrar otro culto, que les fuera común. Por eso, cierto número de familias formaban un grupo, que la lengua griega llamó fratría y la lengua latina curia. El papel de la fratría dentro de la ciudad fue principalmente religioso, pero también se celebraban en ellas actos jurídicos concernientes al estado civil de las personas, tales como la presentación del muchacho de dieciséis años o la presentación de la esposa por el esposo, acto por el cual se consagraba el matrimonio ${ }^{1}$.

En el momento mismo de unirse, las familias creaban una divinidad superior a sus divinidades domésticas. Luego elevaban un altar, encendían el fuego sagrado e instituían un culto sagrado. No había curia (fratría) sin altar y sin un dios protector. El acto religioso era similar en cada familia y consistía principalmente en la comida celebrada en común. Estas comidas religiosas se conservaron durante mucho tiempo en Roma. Las menciona Cicerón llamándolas "dies curiae, convivium" ". Todavía en tiempos de Augusto conservaban todas sus formas antiguas: "En estas moradas sagradas he visto la comida preparada ante el dios:

${ }^{1}$ Cfr. J. Ellul, Historia de las instituciones de la antigüedad: instituciones griegas, romanas, bizantinas y francas, Madrid 1970, p. 27.

${ }^{2}$ Ciceron, De orationes, I. 7, en: M. Winterbottom, Oxford 1984. 
las mesas eran de madera, según la costumbre de los antiguos, y la vajilla de tierra. Los alimentos consistían en panes, tortas de flor de harina y algunas frutas. He visto hacer las libaciones: no caían de áureas o argentadas copas, sino de vasos de varro, y he admirado a los hombres de nuestros días, que tan fieles persisten a los ritos y a las costumbres de sus padres" ${ }^{\text {. }}$

Los días de fiesta, cada fratría se reunía alrededor de su altar. Se sacrificaba una víctima, y las carnes cocidas en el fuego sagrado se distribuían entre los miembros de su fratría. Para formar parte de una fratría había que nacer de un matrimonio legítimo en una de las familias que la componían. La religión de la fratría, como la de la familia, sólo se trasmitía por la sangre. La admisión a la fratría se celebraba en forma religiosa. En presencia de todos los miembros se inmolaba una víctima y se cocía la carne en el altar. Los antiguos creían que estas prácticas de preparar el alimento sobre un altar y compartirlo entre varias personas establecían un lazo indisoluble y una unión santa ${ }^{4}$.

Cada curia o fratría tenía un jefe llamado curión o fratriarca. Su función principal era presidir los sacrificios. Todas las curias se encontraban bajo la supervisión del jefe de los curiones quien se encargaba de notificar la fecha de las fiestas. Los distintos curiones (fratriarcas) eran elegidos por sus curias (fratrías) respectivas. Cada curia (fratría) tenía su lugar de reunión, donde se realizaban los sacrificios especiales. Había allí un hogar y un salón de recepción donde se congregaban los miembros ${ }^{5}$. La curia (fratría) tenía sus asambleas, sus deliberaciones. En ella, como en la familia, había un dios protector, un culto, un sacerdocio, una justicia, un gobierno. La fratría formaba una pequeña sociedad modelada en la de la familia ${ }^{6}$.

En la época imperial, el término curia no se refiere solamente al ámbito religioso, sino designa también la asamblea o Senado municipal de cada ciudad, sobre cuyos miembros pesaban cargas abundantes ${ }^{7}$. El Senado municipal era constituido por cuantos habían desempeñado las magistraturas municipales, y por otros ciudadanos adlecti entre los descendientes de los ex magistrados. La

3 Dionisio de Halicarnaso, II, 23, en: E. Jimenez, E. Sanches (tr.), Historia antigua de Roma, Madrid 1984.

${ }^{4}$ Cfr. N. D. Fustel de Coulanges, La ciudad antigua, Madrid 1931, p. 162-165.

${ }^{5}$ Cfr. Enciclopedia de la antigüedad, vol. I, Buenos Aires 1972, p. 34.

${ }^{6}$ Cfr. N. D. Fustel de Coulanges, La ciudad ..., p. 165.

7 Cfr. F. Gutierrez-Alviz y Armario, Gens, en: Diccionario de Derecho Romano, Madrid 1982, p. 170. 
misma curia elige los titulares de las magistraturas municipales ${ }^{8}$. La curia tenía poder de control en todas las materias. Más tarde la curia eliminó la actividad de las asambleas populares. En la primera mitad del siglo III, los magistrados eran nombrados por la curia. El Estado concedía ventajas y honores a los curiales. Adriano les había otorgado privilegios jurídicos, en virtud de los cuales todo curial se convertía en ciudadano romano?.

Las fratrías estaban agrupadas en tribus. Es probable, como dice Ellul, que las tribus "existieran ya en el origen de los grupos étnicos"10. Durante el período monárquico, el pueblo estaba dividido en tres tribus y en treinta curias (fratrías). Las tribus se diferenciaban por su origen étnico. Eran las de los Ramnes (romanos), Luceres (etruscos) y Titienses (sabinos). Estas tribus tenían diferentes ritos religiosos y diferentes privilegios políticos ${ }^{11}$.

Este nuevo círculo tenía también su religión. En cada tribu hubo un altar y una divinidad protectora. El dios de la tribu era de la misma naturaleza que el de la fratría (curia) o el de la familia. Normalmente era un hombre divinizado, un héroe. Ese héroe daba el nombre a toda la tribu, y tenía su día de fiesta en la que todos los miembros se reunían en la ceremonia religiosa cuya parte principal era la comida ${ }^{12}$.

La tribu como la fratría (curia) festejaba sus asambleas y daba los decretos. Tenía su tribunal y un derecho de justicia sobre sus miembros. Pollux menciona a $\phi \nu \lambda o \beta \sigma \iota \lambda \varepsilon v \varsigma$ (tribunus) que era jefe de la tribu ${ }^{13}$.

La tribu, como la fratría (curia) y la familia, estaba constituida para ser organismo independiente, teniendo un culto especial del que estaba excluido el extraño. Pero, así como varias fratrías se unían en una tribu, del mismo modo pudieron asociarse varias tribus a condición de que se respetase el culto de cada tribu. Según De Coulanges, el día en que se celebró esta alianza fue el inicio de la ciudad ${ }^{14}$. Por eso la ciudad era una confederación, que en los primeros siglos estaba obligada a respetar la independencia religiosa y civil de las tribus, de

\footnotetext{
${ }^{8}$ Cfr. E. Costa, Historia del Derecho Romano público y privado, Madrid 1930, p. 206-207.

9 J. Ellul, Hiatoria ..., p. 352.

10 J. Ellul, Hiatoria ..., p. 27.

11 J. Ellul, Hiatoria ..., p. 182-183.

12 Cfr. N. D. Fustel de Coulanges, La ciudad ..., p. 166.

${ }^{13}$ N. D. Fustel de Coulanges, La ciudad ..., p. 167.

${ }^{14}$ Cfr. N. D. Fustel de Coulanges, La ciudad ..., p. 176.
} 
las curias (fratrías) y de las familias. El hombre ingresa en diversos momentos en estas cuatro sociedades. El niño es admitido primero en la familia, algunos años después entra en la fratría (curia) por una ceremonia religiosa, y por fin teniendo dieciséis o dieciocho años se presenta para ser admitido en la ciudad ${ }^{15}$. Desde entonces está iniciado en el culto público y se convierte en ciudadano.

\section{La religión de la ciudad}

Hablando sobre la religión en las ciudades, vamos a analizar este tema en las tres épocas de la historia romana. Primero en la Roma arcaica, luego en el período de la República y finalmente en el Imperio.

\subsection{En la Roma arcaica}

La principal ceremonia del culto de la ciudad en aquella época era la comida que había de realizarse en común por todos los ciudadanos, en honor de las divinidades protectoras. La religión se manifiesta en el culto público. El sacerdote es el representante religioso de la comunidad, encargado por el Estado para cumplir personalmente los ritos. Los sacerdotes vivían en el mundo cumpliendo sus obligaciones cívicas. El sacerdote puede y debe casarse puesto que algunos ritos requieren la participación en las ceremonias de su esposa y de sus hijos ${ }^{16}$. Otra figura relacionada con la religión de la ciudad es el pontifex. Los pontífices constituían un colegio sacerdotal formado por tres miembros. Uno de ellos gozaba de una posición superior, el pontifex maximus. En la época arcaica, el pontífice máximo aparece como segundo, detrás de la figura del rey que realizaba la mayoría de las funciones sacerdotales, y que fue responsable de todas las cuestiones relacionadas con la organización de la religión pública ${ }^{17}$.

En la época arcaica hay cuatro figuras que tienen mucha importancia en la religión de entonces. Las componen: augures, flamines, salii y vestales.

${ }^{15}$ Cfr. N. D. Fustel de Coulanges, La ciudad ..., p. 177.

${ }^{16}$ Cfr.J. M. Blazquez., Historia de las religiones antiguas. Oriente, Grecia y Roma. Madrid 1993, p. 414-415.

17 Cfr. A. D’Ors., En torno a las raices romanas de la colegialidad, en: A. D’Ors, J Orlandis, A. Hera, Tres estudios históricos sobre la colegialidad episcopal, Pamplona 1965, p. 17-19. 
Augures era el colegio sacerdotal que como misión fundamental tenía la consulta de los auspicios en nombre de la ciudad. Su número era de tres y estaban relacionados con las tres tribus: Ramnes, Tities y Luceres. Los augures eran expertos en la ciencia que interpretaba la voluntad divina. El ejército romano iba siempre acompañado de augures y llevaba consigo un hogar en el que alimentaba día y noche el fuego sagrado ${ }^{18}$.

Los flamines fueron sacerdotes especializados en el culto a una divinidad concreta. Cada uno de ellos era totalmente autónomo respecto a los demás, actúa en solitario y dedica sus actos a un dios particular. Existían quince flamonia, tres mayores y doce menores. Naturalmente los flamines mayores tuvieron mayor importancia y se les denominaba Dialis, por estar dedicado a Júpiter, Marte y Quirinio. Según Tito Livio Numa creó los flamines para que los deberes religiosos del rey no fuesen nunca abandonados: "Pero, como le parecía que en un país belicoso iba a haber más reyes del estilo de Rómulo que de él mismo y que iban a acudir personalmente a las guerras, para evitar que quedasen abandonadas las funciones sacerdotales que competían al rey creó un flamen sacerdote permanente de Júpiter y realzó su figura con una vestimenta especial y una silla curul como la del rey"19.

Los salios eran constituidos por doce sacerdotes. Se trata de un sacerdocio de carácter militar. Había dos categorías de salios: seniores y iuniores. Este grupo de los sacerdotes estaba presidido por un magister y por un praesul, que dirigía la danza, y por un vates que entonaba el canto. La actividad religiosa de los salios ocupaba principalmente el mes de marzo, como preparación ritual a la campaña militar. El elemento principal de los rituales de los salios era la danza con los cantos e invocaciones dirigidas a los distintos dioses, sobre todo a Marte, Jano y Júpiter ${ }^{20}$.

Finalmente, las vestales, era el único sacerdocio estrictamente femenino. El nombre oficial de estas sacerdotisas era el de virgines Vestales. Su principal función era el mantenimiento del fuego sagrado, y además todos los días invocaban a los dioses por la salud de Roma. Estas sacerdotisas representaban la pureza en su más alto grado, al tener intacta su virginidad. En todas las sociedades el hombre ha querido honrar a sus dioses con las fiestas. Todas

${ }^{18}$ Cfr. J. M. Blazquez, Historia de las religiones ..., p. 417-418.

19 Tito Livio, I, 20, 2, en: J. A. Victor Vidal (tr), Historia de Roma desde su fundación, Madrid 1990.

${ }^{20}$ Cfr. J. M. Blazquez, Historia de las religiones ..., p. 423-424. 
las ciudades tenían su fiesta para cada una de las divinidades que habían adoptado como protectoras. En Roma, en el primer día del mes, el pontífice convocaba al pueblo y señalaba las fiestas que habían de observarse en el transcurso del mes. Esta convocatoria se llamaba colatio $^{21}$.

\subsection{En la República romana}

La transición de la monarquía a la ciudad libre no llevaba consigo la ruptura con la religión romana. Al contrario. Observamos en este periodo la dedicación de los edificios religiosos cuya construcción había sido iniciada en la época monárquica. A parte de este hecho surge una nueva figura de rex sacrorum, una de las que mejor define la continuidad en materia religiosa entre la monarquía y la república. Rex sacrorum fue creado tras la caída de la monarquía ante la necesidad de sustituir al monarca en sus deberes religiosos ${ }^{22}$.

Durante el nuevo régimen republicano, la religión romana fue influida por la rivalidad entre patricios y plebeyos. La desigualdad de los plebeyos en el ámbito político, económico y social se notaba también en el de los derechos religiosos. Dicha desigualdad se manifestaba, ante todo, en la imposibilidad de acceder al sacerdocio ${ }^{23}$.

Nos acercaremos ahora a la última fase de la religión romana republicana, que se caracteriza por un profundo desorden. Hablamos del siglo I a.C. Los políticos y jefes militares utilizaban la dedicación de un templo para acentuar su propia gloria individual. En muchos casos utilizaron los bienes de los templos para mantener económicamente las guerras. Esto explica el abandono material y ruina de numerosos templos ${ }^{24}$.

En cuanto al culto de la época republicana hay que destacar que los templos asumían un gran protagonismo tanto en el caso de sacrificios públicos como privados. La función principal del templo era cumplir en él los deberes religiosos de carácter público, ejecutados por magistrados y sacerdotes, o privado. En el primer caso la ocasión más solemne para ofrecer sacrificios era llamado dies natalis del templo, es decir, el aniversario de su construcción, que normalmente

\footnotetext{
${ }^{21}$ Cfr. J. M. Blazquez, Historia de las religiones ..., p. 421-423.

${ }^{22}$ Cfr. J. M. Blazquez, Historia de las religiones ..., p. 438-439.

${ }^{23}$ Cfr. J. M. Blazquez, Historia de las religiones ..., p. 440-441.

${ }^{24}$ Cfr. J. M. Blazquez, Historia de las religiones ..., p. 457-459.
} 
coincidía con el festival en honor de la divinidad tutelar del mismo. El templo asumía también una función económica. El sacerdocio de cada templo disponía de un acra, es decir, de una caja donde se depositaban las rentas provenientes del santuario para el mantenimiento del culto. Los templos tenían en ocasiones asignadas funciones civiles y políticas. En los templos se celebraba las sesiones senatoriales. Los cónsules disponían de unas oficinas en los templos desde donde convocaban la Asamblea ${ }^{25}$.

Finalmente, en este periodo, llama atención la figura de los ediles. Fueron los principales responsables del mantenimiento de los templos públicos con fondos procedentes de los mismos templos o de multas y sanciones, como dice Livio: "En este mismo año Geno y Quinto Ogulnio, ediles curules, persiguieron a algunos usureros y con el producto de la confiscación de sus bienes se construyeron la puerta de bronce del Capitolio, vasos de plata para decorar tres mesas colocadas en el santuario de Júpiter y un Júpiter en cuadriga en el pináculo y, junto a la higuera Ruminal, las estatuas de los infantes fundadores de la ciudad bajo las ubres de la loba, y pavimentaron con adoquines cuadrados la calle desde la puerta Capena hasta el templo de Marte"26.

La responsabilidad diaria del templo correspondía al aedituus que podía ser libre o esclavo y era encargado de cerrar de noche los templos en Roma $^{27}$.

\subsection{En el Imperio romano}

En el año 12 a.C. Augusto fue investido como pontifex maximus, cargo que a partir de entonces va a permanecer asociado a su figura. Augusto fue el último responsable de la vida religiosa del Estado. Diez años después se le confirió el título de Pater patriae, que hacía de él el sacerdote supremo de la familia romana. El culto imperial, proclamado y organizado por la iniciativa del propio Augusto, donde él mismo fue considerado como dios, existía sólo en Roma e Italia o allí donde fueron los romanos ${ }^{28}$.

El culto imperial se desarrolló a dos niveles: a nivel provincial, y en las ciudades.

${ }^{25}$ Cfr. J. M. Blazquez, Historia de las religiones ..., p. 477-481.

26 Tito Livio, X, 23, 11-12.

${ }^{27}$ En los santuarios rurales o con posesión de tierras, viene mencionado un vilicus. Cfr. J. M. Blazquez, Historia de las religiones ..., p. 477.

${ }^{28}$ Cfr. J. M. Blazquez, Historia de las religiones ..., p. 537-548. 
Hablando sobre el culto imperial en las provincias hay que tener presente las diferentes formas de la vida religiosa en las provincias orientales y las occidentales. Las ciudades griegas del Imperio mantuvieron con sus modos de vida sus propias peculiaridades religiosas. Entre ellos hay que destacar las fiestas y procesiones públicas. En las partes orientales del Imperio se concentra la mayor parte de los centros oraculares con las prácticas adivinatorias. Para los orientales el emperador es divino y, una vez muerto es un dios, tiene su templo y su clero. Esta postura se adaptó en el Occidente en el siglo III ${ }^{29}$. El conjunto ritual romano fue más poderoso en Occidente donde gozaba de la difusión de la lengua latina. En las provincias occidentales, Júpiter aparece como Optímus Máximus y se le invoca, sobre todo, en los ambientes militares y administrativos. Si comparamos las divinidades propiamente romanas con las indígenas ${ }^{30}$ podemos concluir que aquellas ocuparon un lugar importante en la vida religiosa de las provincias. Los más fervientes devotos de ese culto eran los medios romanos o fuertemente romanizados al servicio del ejército y de la administración ${ }^{31}$.

Ahora bien, ¿como se desarrollaba el culto imperial en las provincias? Participar en el culto imperial provincial como flamen fue el máximo honor al que podían aspirar los provinciales. El flamen era un cargo sacerdotal. Era elegido por los delegados de las ciudades de la provincia en una reunión anual del concilium. Ese cargo lo podía ocupar solamente un ciudadano romano de origen local y que había desempeñado las magistraturas en su ciudad de origen. El flamen debía residir en la capital provincial donde presidía las fiestas y ceremonias en honor de los emperadores divinizados. Las fiestas comenzaban con un solemne sacrificio de toros ante el altar provincial. Luego tenían lugar los banquetes, juegos y competiciones ${ }^{32}$.

En cuanto al culto municipal, existían los sacerdotes municipales del culto imperial, que también llevaban el título de flamen, seguido el nombre de la

${ }^{29}$ Cfr. J. Ellul, Historia ..., p. 386.

${ }^{30}$ Los celtas tenían grandes dioses de la naturaleza, sus hadas benéficas y sus ninfas de los ríos y los bosques; los tracios poseían su dios de selvas, jardines y viñedos, cazador y guerrero; los lirios tenían un dios de las montañas; los africanos poseían sus antiguas deidades semitas y bereberes; los sirios reconocían muchas variedades locales del dios-sol. Cfr. M. Rostovtzeff, Roma. De los orígenes a la última crisis, Buenos Aires 1970, p. 242.

${ }^{31}$ Cfr. J. M. Blazquez, Historia de las religiones ..., p. 549-550.

32 Cfr. J. M. Blazquez, Historia de las religiones ..., p. 563. 
ciudad o del emperador divinizado como flamen divi Vespasiani, flamen divi Traiani, etc. Los flamines de la ciudad elegidos para un año, gozaban de un rango social elevado. Casi todos ellos eran ciudadanos romanos y procedían de la rica y dominante aristocracia local ${ }^{33}$.

Todo el culto imperial fue financiado por las élites urbanas. Pero el empobrecimiento de la mayor parte de la población en los finales del siglo II d. C., la crisis del reinado de Marco Aurelio y las guerras civiles tuvieron consecuencias inmediatas para el culto imperial. Desde entonces, aunque sobrevivió el culto, las manifestaciones de piedad comenzaron a hacerse más raras y menos espontáneas ${ }^{34}$.

\section{La personalidad del derecho y de la ley}

La palabra ius es propiamente romana y significa "lo justo", es decir, el orden judicial socialmente admitido, formulado por los que saben de lo justo: por los iuris prudentes ${ }^{35}$. Según D’Ors, el ámbito del ius es el que cubre el interés de los juristas, por eso posteriormente se llega a hablar del ius criminal, fiscal, militar, político. En cambio, el ius empieza por estar en estrecha relación con la religión, y se habla de ius divinum para designar prescripciones pertinentes a los ritos religiosos, de los que los antiguos juristas, que solían reservarse a la vez el cargo religioso de pontifices, se ocupaban especialmente. Para los romanos, la religión consistía en un intercambio de favores entre los hombres y los dioses. El carácter formal era común a los antiguos actos jurídicos y a los actos religiosos: tanto uno como otros producían sus efectos a causa de su propia forma. La misma auctoritas de los juristas se apoya en la reverencia religiosa. Esta autoridad no es esencialmente distinta de la de los augures, cuya intervención era necesaria para poder celebrar los actos principales de la vida política, hasta que los magistrados

${ }^{33}$ Cfr. J. M. Blazquez, Historia de las religiones ..., p. 564. Igualmente ligados al culto imperial eran llamados seviri augustales y los augustales. Ellos están presentes en Occidente durante los primeros años del Imperio.

${ }^{34}$ Cfr. J. M. Blazquez, Historia de las religiones ..., p. 565.

${ }^{35}$ Cfr. A. D’Ors, Derecho privado romano, Pamplona 1997, p. 43. Etimológicamente la palabra ius está relacionada con Iovis-Iupiter, el dios que castiga el perjurio. En su concepción originaria, ius se dice propiamente del acto de fuerza que realiza formalmente una persona, y que la sociedad, mediante sus jueces, reconoce como ajustado a las conveniencias. 
romanos llegaron a tener la facultad de realizar tal función interpretativa mediante la auspicatio ${ }^{36}$.

La primera manifestación del derecho romano arcaico es la tradición práctica de los antepasados, los mores maiorum. A mediados del siglo v a.C. tiene lugar una codificación de preceptos jurídicos, y también funerarios, que se llama la Ley de las Doce Tablas. Esta ley fue superada por el derecho posterior, pero nunca fue expresamente derogada. La ley decenviral es la primera fuente del derecho de los Romanos. Este es el derecho propio de los ciudadanos romanos, que constituyen Populus Romanus ${ }^{37}$.

Los juristas romanos constituyen el derecho como un saber autónomo, aunque no dejan de tomar en consideración las realidades sociales de su época como esclavitud, monogamia, etc. Los romanos tuvieron justa conciencia de la superioridad de su ius civile. En él hay instituciones que se consideran como de validez general para todos los pueblos relacionados con Roma, porque se fundan en el principio de lealtad a la palabra dada, es decir, la fides. Los filósofos romanos llaman a ese derecho común ius gentium o naturale, y algunos especularon con la idea de que las instituciones aplicables a los peregrini procedían del ius gentium, en especial, relativas al comercio de esclavos y a la misma esclavitud ${ }^{38}$.

La lex es una declaración de potestad, que vincula tanto al que la da como al que la acepta. La ley puede ser privada o pública ${ }^{39}$. La autorización popular de la ley se recababa para que la ley vinculase a todos los ciudadanos. Los peregrini,

${ }^{36}$ Se hablaba, a veces, del carácter mágico de los ritos religiosos. D’Ors opina, que esto "supone una confusión entre la religión, que, en una forma u otra, presupone una operatividad divina, y la magia, que pretende contar para sus manipulaciones con la operatividad de fuerzas no-divinas. La fuerza del juramento, tan especial para el ius, nada tiene que ver con la magia, sino con una confianza en Júpiter, que es netamente religiosa; la execración que produce el perjurio y otros crímenes exponía a la venganza divina y privaba de la protección humana”. A. D’Ors, Derecho privado romano, p. 45-46.

${ }^{37}$ La Ley de las Doce Tablas fue dada por un colegio de magistrados con encargo legislativo: los decemviri legibus scribundis (451 a 449 a.C); por eso llamamos a la de los Doce Tablas la "ley decenviral". A. D’Ors, Derecho privado ..., p. 47-48.

${ }^{38}$ Fides es una idea central del pensamiento jurídico y político de Roma. Es una virtud del más poderoso. Así, la fides deorum es la protección que dispensan los dioses, y la fides Romana es la firmeza de Roma respecto a los propios clientes. Cfr. A. D’Ors, Derecho privado ..., p. 61.

${ }^{39}$ Lex privata es aquella que declara el que dispone de lo suyo en un negocio privado. Lex publica, en cambio, es la que declara el magistrado y reciben los comicios con su autorización. Cfr. A. D’Ors, Derecho privado ..., p. 63-64. 
en cambio, no quedaban vinculados por la ley, pues no habían intervenido en los comicios. Por ejemplo, la ley Oppia, del 215 a. C., prohibía el lujo en el atuendo de las mujeres, pero no afectaba a las peregrinas ${ }^{40}$, la ley Aelia Sentia hubo de ser extendida a los peregrinos mediante un senadoconsulto ${ }^{41}$.

Según D’Ors entre ius y la lex hay una clara antítesis. "En principio - señala D’Ors - la lex no modifica el ius, y si se dice que es fuente del ius, esto se debe a que los nuevos datos de la ley pueden ser asimilados por la Jurisprudencia. (...) Las XII Tablas son, pues, fuente del ius legitimum, así como otras leyes que de algún modo interesaban a los juicios privados"42.

En el Principado, las leyes ceden su función a los senadoconsultos, y sólo en la época post-clásica se vuelven a dar leges, como expresión del poder legislativo del emperador, en contraposición a la tradición doctrinal del ius.

\section{El gobierno de la ciudad}

Durante la monarquía quien tenía el máximo poder era el rey. Él es jefe religioso, juez, comandante militar y representante de la ciudad. El rey era el sumo sacerdote cuya principal función era vigilar los cultos antiguos e invocar la protección de los dioses sobre el pueblo. Como explica Karlowa ${ }^{43}$ el rey no era un dios ni descendiente de dioses sino, un hombre. Como sumo sacerdote regulaba toda la vida religiosa de la ciudad. Bajo su potestad estaban los colegios de sacerdotes que le ayudaban en sus funciones. Los propios atributos externos del rex fueron: corona, toga de púrpura, trono de marfil. Estos son los atributos que

40 "Decía Catón que no habría envidia alguna entre unos y otros, puesto que ninguna sería poseedora. Pero, por Hércules, todas ellas sufren y se sublevan cuando ven que a las mujeres de los aliados latinos se les permiten los ornatos que a ellas se les niegan, cuando las ven llamando la atención con el oro y la púrpura y yendo en coche por la ciudad mientras que ellas las siguen a pie, como si el imperio tuviera su sede en las ciudades de los otros y no en la suya". Cfr. Tito Livio, 34, 7, 5-6.

41 "Ha de saberse, en fin, que lo dispuesto por la ley Aelia Sentia de que no se hagan libres los manumitidos para defraudar a los acreedores se aplica también a los extranjeros, sin que en cambio tengan aplicación a ellos las demás normas de esta ley”. Cfr. Gayo, 1, 47, en: M. Hernandez-Tejero (tr.), Instituciones, Madrid 1985.

${ }^{42}$ A. D'Ors, Derecho privado ..., p. 67.

${ }^{43}$ J. Karlowa, Römische Rechtsgeschichte, vol. I, Leipzig 1885, p. 27 ss. 
los hombres asignaban a los dioses, y aunque los reyes eran simples mortales, estaban más cercanos a los dioses que el común de los ciudadanos ${ }^{44}$.

El rey tenía unos poderes militares en estrecha conexión con el aspecto religioso de su actividad. Las principales competencias del rey en esta materia era la suprema dirección de la guerra y la organización de la defensa de la ciudad. También le corresponde imponer medidas de disciplina, declarar la guerra, concluir la paz y alianzas con otros pueblos o nombrar sus auxiliares militares ${ }^{45}$.

Durante el régimen republicano el rey fue reemplazado por el magistrado. Ahora él es un sacerdote y al mismo tiempo un jefe político. En Roma el magistrado del máximo rango es llamado cónsul. Él representa a la ciudad. De él dependen los auspicios, los ritos, la oración, la protección de los dioses. Un cónsul es algo más que un hombre, es el intermediario entre el hombre y la divinidad. Tito Livio nos cuenta que una vez privado el ejército de su jefe, queda al mismo tiempo privado de la protección celeste ${ }^{46}$.

La primera regla para la elección de un magistrado era que fuera nombrado conforme a los ritos. El magistrado gobernaba al pueblo según las leyes: "Del mismo modo que las leyes gobiernan a los magistrados, así el magistrado gobierna al pueblo, y puede decirse en verdad que el magistrado es una ley con voz, y la ley un magistrado sin ella"47.

La ciudad deseaba encontrar en su magistrado al hombre más amado de los dioses. En Roma se hizo una especie de examen de preguntas al cónsul. Esas preguntas sólo se referían a la aptitud religiosa del magistrado ${ }^{48}$.

En el imperio romano a la cabeza del Estado está el príncipe, emperador. El poder del emperador comprendía el mando de los ejércitos, el derecho de declarar la guerra y de hacer los tratados de paz. Tenía derecho también de fundar colonias, regular su condición jurídica, modificar los estatutos existentes, conceder a ciudades extranjeras o a individuos extranjeros la participación de la ciudadanía romana ${ }^{49}$.

${ }^{44}$ Cfr. J. M. Torrens, Las elecciones episcopales en la historia de la Iglesia, Barcelona 1972, p. $72-74$.

${ }^{45}$ Cfr. J. M. Torrens, Las elecciones episcopales en la historia de la Iglesia, p. 75.

46 Tito Livio, XXVII, 44.

47 Cicerón, De legibus, III, 1, 2.

${ }^{48}$ Cfr. N. D. Fustel de Coulanges, La ciudad ..., p. 258-267.

${ }^{49}$ Cfr. E. Costa, Historia del Derecho romano público y privado, Madrid 1930, p. 176. 
El emperador es siempre de pleno derecho gran pontífice, por tanto, jefe religioso del Estado. En Roma en los templos públicos y en los oratorios particulares, prevalece la costumbre de colocar las imágenes del emperador vivo al lado de las divinidades del Estado ${ }^{50}$.

Como magistrado, el emperador tiene el derecho de publicar las órdenes, que tienen fuerza obligatoria durante toda su vida. El príncipe, como los antiguos reyes y como los magistrados de la república, tenía su consejo. Augusto llamó para constituirlo a los cónsules, a algunos otros magistrados y senadores. En este consejo, llamado concilium, auditorium, el emperador deliberaba sobre los asuntos importantes y particularmente sobre los procesos que le eran elevados ${ }^{51}$.

El emperador tenía también el poder proconsular. Este elemento del poder imperial tenía gran influencia en la organización del Estado introduciendo las prácticas de la administración provincial, que acabaron por invadir todas las partes del imperio, sometiéndolas a un régimen uniforme. La administración de las provincias que le estaban sometidas, le proporcionaba considerables recursos pecuniarios, y tenía en su cohorte pretoriana un cuerpo de hombres que ejecutaban sus órdenes. El primero de enero de cada año, el senado, el pueblo y las legiones presentaban el juramento de fidelidad al emperador. A partir del siglo II se encuentra en el trono dos o más emperadores. Marco Aurelio reinó con Vérus y más tarde con Commodus, Séptimo Severo tuvo por su corregente a su hijo Antonius Caracalla, el cual reinó más tarde con su hermano Geta ${ }^{52}$.

La mayoría de las antiguas magistraturas permanecía durante la época imperial. Así pues, los cónsules continuaron gozando de los mayores honores, pero sin ningún poder. Los ediles, cuyo número había sido aumentado por Julio César, desaparecieron hacia la misma época. De todas las magistraturas la pretura fue la que conservo más importancia. El número de los pretores en los tiempos de Marco Aurelio aumentó hasta diez y ocho. Aunque en los tiempos del Imperio de una u otra manera existen los funcionarios de la época anterior, sin embargo el poder efectivo fue transferido a nuevos funcionarios creados por el emperador. El primero de ellos es el gobernador de la ciudad, proefectus

${ }^{50}$ Cfr. E. Costa, Historia del Derecho romano público y privado, p. 181.

${ }^{51}$ Cfr. C. Maynz, Curso de Derecho romano, Barcelona 1887, p. 266-267.

${ }^{52}$ Cfr. C. Maynz, Curso de Derecho romano, p. 268-269. 
urbi. Se creó esta función con ocasión de las guerras civiles, para mantener la seguridad de la ciudad.

"Pero su principal gloria (de padre de Lucio Pisón) le venía de que, siendo prefecto de la Ciudad, desempeñó con admirable tacto un mandato recientemente convertido en permanente yespecialmente difícil porque se había perdido la costumbre de obedecer" ${ }^{33}$.

El prefecto del pretorio, prefectus proetorii, sólo era al principio el jefe de la guardia imperial, pero a lo largo del tiempo esta función adquirió importancia, de manera que el que la desempeñaba, era considerado como el primer personaje del Estado después del emperador. El prefectus vigilum era el jefe de los vigilantes de noche encargados de evitar los robos e incendios. El prefectus annonoe vigilaba los abastecimientos de Roma ${ }^{54}$. Los prefecti oerarii tenían la administración del tesoro y cierta jurisdicción en los negocios fiscales.

"Entonces Claudio puso de nuevo al frente a los cuestores, ypara que su celo no fuera menor por miedo a los resentimientos, les prometió acceso a los honores fuera de turno; pero les faltaba la madurez de la edad a los primeros que ejercieron esta magistratura. Por ello Nerón escogió a hombres que hubieran desempeñado la pretura y que tuvieran experiencia probada" ${ }^{35}$.

Todos estos funcionarios eran nombrados y destituidos por el emperador.

Concluyendo, podemos destacar que la principal característica del sistema de gobierno en el Imperio, estribaba en la concesión del máximo de iniciativa posible a la unidad local, es decir, a la ciudad con su propio gobierno autónomo.

\section{Las colonias y la diócesis como estructuras personales del Imperio romano}

En el Imperio Romano se produce un fenómeno social que, aún teniendo lugar en el seno mismo de una unificación, revela la permanencia de las particularidades étnicas. En ese párrafo nos ocuparemos de dos estructuras que corresponden al dicho fenómeno social: las colonias y la diócesis.

\footnotetext{
53 Tácito, Annales, VI, 10, 11.

${ }^{54}$ Cfr. Tito Livio, 17.

55 Tácito, Annales, XIII, 28, 29.
} 


\subsection{Las colonias romanas}

Las colonias eran ciudades fundadas por Roma, que enviaba a ellas ciudadanos para ocupar un territorio perteneciente a un pueblo vecino. Las colonias romanas tenían, sobre todo, un objetivo militar. Este tipo de colonias estaban compuestas por ciudadanos romanos enviados a un país enemigo, constituyendo una guarnición instalada en él. La colonia romana estaba compuesta en un principio por 300 hombres. A lo largo del tiempo este número aumenta, hasta los 6.000 en el siglo II. A cada uno de los colonos se asignaba en propiedad un pequeño lote de terreno, generalmente de dos a cinco iugera ${ }^{56}$. Estos colonos estaban dirigidos por unos comisarios de Roma; construían una ciudad y tenían todos ellos el título de ciudadano romano, conservando sus derechos políticos en Roma ${ }^{57}$.

Las colonias eran modeladas sobre el ejemplo de Roma. A imitación de Roma tenían su propia asamblea, senado, magistrados. En definitiva, no eran comunidades autónomas, sino estrictamente ligadas a Roma, no tenían ordenamiento constitucional propio, sino el de Roma. Con el tiempo llegaron a tener una cierta autonomía jurisdiccional y administrativa ${ }^{58}$.

Las colonias fueron un instrumento muy importante para lograr la unificación nacional de la península itálica. Más tarde, con la fundación de las colonias transmarinas (es el caso de Hispania), las colonias fueron un instrumento eficaz de romanización del Mediterráneo.

El caso de Hispania en esta materia es significativo. Las nuevas formas político-administrativas que Roma impuso sobre los territorios conquistados iban acompañadas, al mismo tiempo, de nuevas formas de organización social. Esta situación no exigía, en cambio, la ruptura brusca de la organización social indígena. La organización gentilicia se mantuvo largo tiempo en muchas comunidades. Una gens, unidad superior, englobaba a varias gentilidades, y cada una de éstas a varias familias. La organización natural en la que eran válidos los vínculos de parentesco se terminaba en la gens. Esta organización gentilicia servía como base para la fijación de los límites territoriales de cada unidad. Los

${ }^{56}$ Un iugerum es la cantidad de tierra que una yunta de bueyes puede arar en un día. Cfr. Plinio el Viejo, Historia natural, XVIII, 9. "Et quoniam praeparatus est ager, nunc indicabitur natura frugum. Sunt autem duo prima earum genera: frumenta, ut triticum, hordeum, et legumina, ut faba cicer. Differentia notior quam ut indicari deceat".

${ }^{57}$ Cfr. J. Ellul, Historia ..., p. 257-258.

${ }^{58}$ Cfr. J. M. Ttorrens, Las elecciones..., p. 311. 
jefes de las unidades gentilicias gozaban de un prestigio superior en el campo político, militar y religioso ${ }^{59}$.

Roma ha conocido en las fases primitivas de su historia una organización análoga a la indígena de los territorios de Hispania, concretamente de la Meseta. Incluso en la estructura onomástica altoimperial seguía conservando las referencias a esta organización. Así, por ejemplo, un personaje mencionado en una inscripción de Frómista (Palencia) se llama Lucius Antonius Marci filius Galeria Pudens, en donde tenemos el nombre personal (Lucius), la indicación del padre (Marci filius), la referencia a la gran familia (Antonia) y la referencia a la tribu (Galeria). Pues, esta familia romana servía de vehículo para la transmisión de la cultura y de la religión romana. El modelo de la familia romana ha servido incluso para los que no tenían derechos de ciudadanía ${ }^{60}$.

En las provincias célticas el Imperio mantenía y reforzaba el sistema existente, social y económico basado en el clan. Los procuradores imperiales y la aristocracia nativa, servía como intermediario entre Roma y el pueblo, y se hacía responsable del comportamiento de éste. La aristocracia dirigía toda la vida local de las tribus, bajo el control de los gobernadores romanos. La civitas celta se transformó en una ciudad romana y a veces recibió del gobierno romano el título y privilegios de una colonia ${ }^{61}$.

África fue también un lugar de colonización. Cierto número de colonos itálicos, sobre todo los comerciantes y banqueros, fueron acudiendo a las ciudades fenicias y bereberes que ya existían. Durante el tiempo del Imperio, algunas ciudades fueron colonizadas por veteranos romanos, a quienes Roma concedió extensas parcelas que se tomaban del territorio de la ciudad. Así, surgieron centros urbanos que contenían dos comunidades: los fenicios originarios y los romanos recién llegados. En el transcurso del tiempo estas dos comunidades se mezclaron, y la población tuvo carácter mixto ${ }^{62}$.

Las colonias, eran también un instrumento de difusión de la religión romana. Los sectores militares y los cuadros de la Administración central se nos presentan como los más fieles devotos de los dioses romanos. Júpiter fue la divinidad

${ }^{59}$ Cfr. J. Mangas Manjarres - J. M. Solana Sáinz, Romanización y germanización en de la Mestea Norte, en: Historia de Castilla y Leon, Valladolid 1985, p. 68.

${ }^{60}$ Cfr. J. Mangas Manjarres - J. M. Solana Sáinz, Romanización y germanización en de la Mestea Norte, p. 69.

${ }^{61}$ Cfr. M. Rostovtzeff, Roma ..., p. 194.

${ }^{62}$ Cfr. M. Rostovtzeff, Roma ..., p. 195. 
más venerada en los sectores militares. Durante el Imperio se consolida su advocación de protector del ejército. Por eso allí donde hubo una unidad militar, Júpiter recibió culto. Los sectores militares, y de modo mucho más claro aún los funcionarios de la Administración central, fueron muy sensibles a la propaganda religiosa emitida desde Roma.

En general la colonia tenía el mismo culto que la metrópoli. Podía tener algunos dioses particulares, pero debía conservar y honrar a las divinidades de la ciudad de que procedía. Se conservaba, en muchos casos la antigua práctica, según la cual la colonia recibía de la metrópoli los pontífices que presidían su culto y que velaban por la conservación de los ritos ${ }^{63}$.

\subsection{El concepto de diócesis}

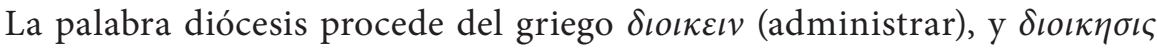
(administración), y ha pasado a las lenguas romanas a través del latín (dioecesis). Como señala Domingo ${ }^{64}$, en su origen etimológico, el término diócesis no está cargado de ningún matiz territorialista ni personalista.

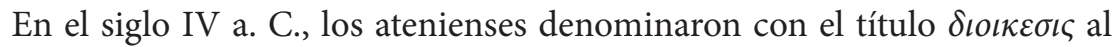
funcionario de más alto rango dedicado a la administración financiera. Más tarde, a comienzos del siglo III a. C., esta función fue desempeñada por un colegio de magistrados. La palabra diócesis penetra en Roma a través de las provincias helenísticas, donde se empleó el concepto para referirse a ciertos distritos jurisdiccionales similares a los conventus iuridici de otras partes del Imperio romano ${ }^{65}$.

Durante la época de Diocleciano (284- 305 d. C.) se llevó a cabo una de las reformas más radicales del gobierno y de la administración pública romana. Diocleciano dividió el Imperio en cuatro grandes prefecturas, dos en Oriente (la prefectura de Oriente y la de Illiria) y dos en Occidente (la prefectura en Italia y la de las Galias. Estas extensas circumscripciones administrativas subdividió en doce diócesis: Oriente, Póntica, Asiana, Tracia, Mesia, Panonia, Britania, Galia,

${ }^{63}$ Cfr. N. D. Fustel de Coulanges, La ciudad ..., p. 311-312.

${ }^{64}$ R. Domingo, Los principios de territorialidad y de personalidad en el concepto de diócesis, en: P. Rodriguez, (ed.) Iglesia Universal e Iglesias Particulares. IX Simposio Internacional de Teología de la Universidad de Navarra, Pamplona 1989, p. 273-278.

${ }^{65}$ R. Domingo, Los principios de territorialidad y de personalidad en el concepto de diócesis, p. 273. 
Vienense, Italia, Hispania, África. Las diócesis fueron gobernadas por los vicarii imperii, que gozaban fundamentalmente de atribuciones fiscales y judiciales ${ }^{66}$.

"Se negaría la evidencia - señala Domingo - si se afirmara que concepto de diócesis no está íntimamente unido al de territorio, ya que, (...) Diocleciano dividió territorialmente el Imperio en prefecturas, diócesis y provincias. Ahora bien, tampoco sería cierto advertir que, en el Imperio Romano, la concepción territorialista prevaleció sobre la personalista, ni tan siquiera a partir de la Constitutio Antoniana del 212 por la que Caracala concedió la ciudadanía romana a todos los súbditos libres del Imperio. En efecto, el populus Romanus estaba formado por los ciudadanos romanos (cives), cuya unidad venía determinada por el nomen Romanum"67.

Según D’Ors, la contraposición entre polis y civitas permite una observación muy significativa. Los politai presuponen una polis y la civitas presupone unos cives. "La prioridad de lo personal sobre lo territorial - señala D'Ors - aparece en esta derivación con toda claridad. La palabra polis, relacionada con polus y con plethos, parece tener su mejor correspondencia en un término perdido en latín, pero que nos conservan el osco touto y el umbro totam, que se refieren igualmente a una concentración humana en un territorio determinado. Civis, en cambio, se relaciona con la raíz de palabras germánicas que indican un vínculo familiar”68.

El término diócesis fue asumido por el lenguaje eclesiástico en el Código Teodosiano, del año 376. En el año 381, aparece de nuevo la palabra diócesis en el canon 2 del Concilio de Constantinopla, y posteriormente en el canon 9 del Concilio de Calcedonia (451) ${ }^{69}$.

${ }^{66}$ R. Domingo, Los principios de territorialidad y de personalidad en el concepto de diócesis, p. 273.

${ }^{67}$ R. Domingo, Los principios de territorialidad y de personalidad en el concepto de diócesis, p. 274.

68 A. D’Ors, Sobre el no-estatismo de Roma, en IDEM, Ensayos de Teoría Política, Pamplona 1979, p. 59.

${ }^{69}$ Estos concilios emplean la palabra "diócesis" como extensión territorial al frente de la cual se sitúa un exarca o patriarca. La historia del término diócesis en este nuevo sentido tiene distintos significados en Oriente y en Occidente. En Oriente, la diócesis era una circunscripción territorial extensa, que comprendía diversas provincias eclesiásticas. En Occidente, en cambio, la palabra diócesis no tuvo tanto éxito porque no se dio la equiparación con el concepto de diócesis civil que se produjo en Oriente. Cfr. R. Domingo, Los principios ..., p. 276. 
Para resumir el tema de las estructuras personales vinculadas con la civitas antigua hay que destacar los siguientes datos:

- El concepto civitas puede designar un complejo de pueblos o el territorio de una tribu;

- Puesto que la religión doméstica prohibía a dos familias mezclarse e identificarse, había la posibilidad de que varias familias, sin sacrificar nada de su religión particular, pudieran unirse para celebrar otro culto, que les fuera común. Por eso, cierto número de familias formaban un grupo, que la lengua griega llamó fratría y la lengua latina curia. El papel de la fratría dentro de la ciudad fue principalmente religioso, pero también se celebraban en ellas actos jurídicos;

- La tribu, como la fratría y la familia, estaba constituida para ser organismo independiente, teniendo un culto especial del que estaba excluido el extraño. Pero, así como varias fratrías se unían en una tribu, del mismo modo pudieron asociarse varias tribus a condición de que se respetase el culto de cada tribu;

- En todas las sociedades el hombre ha querido honrar a sus dioses con las fiestas. Todas las ciudades tenían su fiesta para cada una de las divinidades que habían adoptado como protectoras. Así se formaron muy personales formas del culto en Roma arcaica comoen el imperio Romano;

- Las estructuras personales las vemos en el tema de personalidad del derecho y de la ley. Los juristas romanos constituyen el derecho como un saber autónomo, aunque no dejan de tomar en consideración las realidades sociales de su época como esclavitud, monogamia, etc. Los romanos tuvieron justa conciencia de la superioridad de su ius civile. La principal característica del sistema de gobierno en el Imperio, estribaba en la concesión del máximo de iniciativa posible a la unidad local, es decir, a la ciudad con su propio gobierno autónomo;

- Las colonias eran modeladas sobre el ejemplo de Roma. A imitación de Roma tenían su propia asamblea, senado, magistrados. En definitiva, no eran comunidades autónomas, sino estrictamente ligadas a Roma, no tenían ordenamiento constitucional propio, sino el de Roma. Con el tiempo llegaron a tener una cierta autonomía jurisdiccional y administrativa. Las colonias fueron un instrumento muy importante para lograr la unificación nacional de la península itálica. 


\section{Bibilography}

Blazquez J. M., Historia de las religiones antiguas. Oriente, Grecia y Roma. Madrid 1993.

Costa E., Historia del Derecho romano público y privado, Madrid 1930.

D’Ors A., Derecho privado romano, Pamplona 1997.

Ellul J., Historia de las instituciones de la antigüedad: instituciones griegas, romanas, bizantinas y francas, Madrid 1970.

Fustel de Coulanges N. D., La ciudad antigua, Madrid 1931.

Karlowa J., Römische Rechtsgeschichte, vol. I, Leipzig 1885.

Maynz C., Curso de Derecho romano, Barcelona 1887.

Rostovtzeff M., Roma. De los orígenes a la última crisis, Buenos Aires 1970.

Torrens J. M., Las elecciones episcopales en la historia de la Iglesia, Barcelona 1972. 